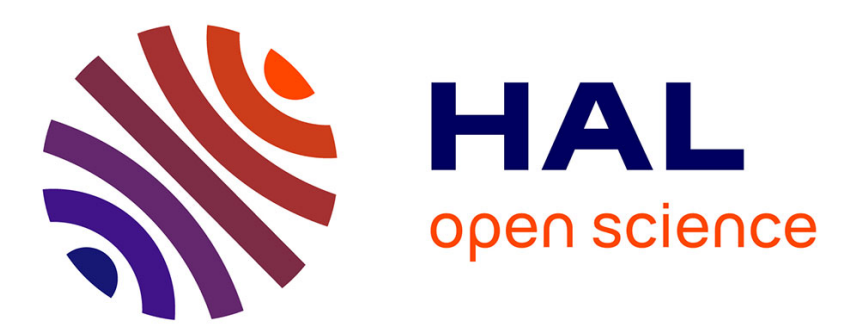

\title{
Accumulation of thymidine-derived sugars in thymidine phosphorylase overexpressing cells
}

\author{
I.V. Bijnsdorp, K. Azijli, E.E. Jansen, M.M. Wamelink, C. Jakobs, E.A. \\ Struys, M. Fukushima, F.A.E. Kruyt, G.J. Peters
}

\section{- To cite this version:}

I.V. Bijnsdorp, K. Azijli, E.E. Jansen, M.M. Wamelink, C. Jakobs, et al.. Accumulation of thymidinederived sugars in thymidine phosphorylase overexpressing cells. Biochemical Pharmacology, 2010, 80 (6), pp.786. 10.1016/j.bcp.2010.05.009 . hal-00608939

\section{HAL Id: hal-00608939 \\ https://hal.science/hal-00608939}

Submitted on 16 Jul 2011

HAL is a multi-disciplinary open access archive for the deposit and dissemination of scientific research documents, whether they are published or not. The documents may come from teaching and research institutions in France or abroad, or from public or private research centers.
L'archive ouverte pluridisciplinaire HAL, est destinée au dépôt et à la diffusion de documents scientifiques de niveau recherche, publiés ou non, émanant des établissements d'enseignement et de recherche français ou étrangers, des laboratoires publics ou privés. 


\section{Accepted Manuscript}

Title: Accumulation of thymidine-derived sugars in thymidine phosphorylase overexpressing cells

Authors: I.V. Bijnsdorp, K. Azijli, E.E. Jansen, M.M.

Wamelink, C. Jakobs, E.A. Struys, M. Fukushima, F.A.E.

Kruyt, G.J. Peters

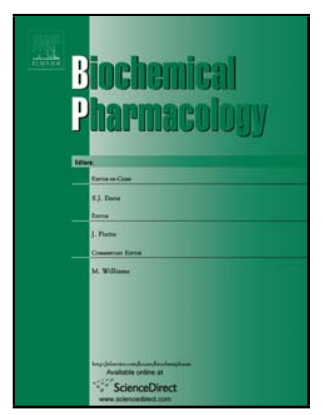

PII:

S0006-2952(10)00348-5

DOI:

doi:10.1016/j.bcp.2010.05.009

Reference:

BCP 10564

To appear in: $\quad B C P$

Received date: $\quad 9-2-2010$

Revised date: $\quad 10-5-2010$

Accepted date: $\quad 11-5-2010$

Please cite this article as: Bijnsdorp IV, Azijli K, Jansen EE, Wamelink MM, Jakobs C, Struys EA, Fukushima M, Kruyt FAE, Peters GJ, Accumulation of thymidine-derived sugars in thymidine phosphorylase overexpressing cells, Biochemical Pharmacology (2008), doi:10.1016/j.bcp.2010.05.009

This is a PDF file of an unedited manuscript that has been accepted for publication. As a service to our customers we are providing this early version of the manuscript. The manuscript will undergo copyediting, typesetting, and review of the resulting proof before it is published in its final form. Please note that during the production process errors may be discovered which could affect the content, and all legal disclaimers that apply to the journal pertain. 


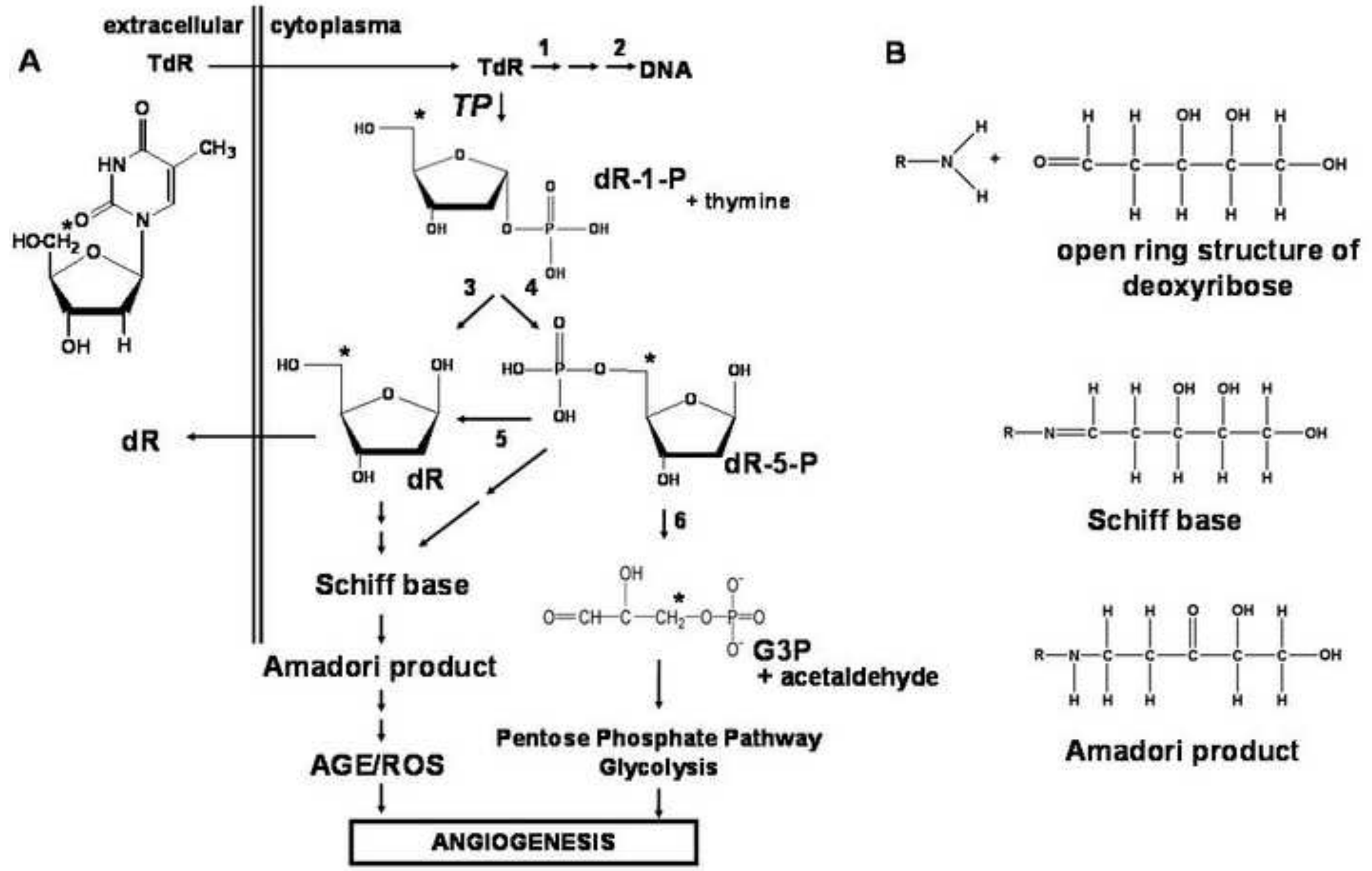


Figure 2 Bijnsdorp et al.

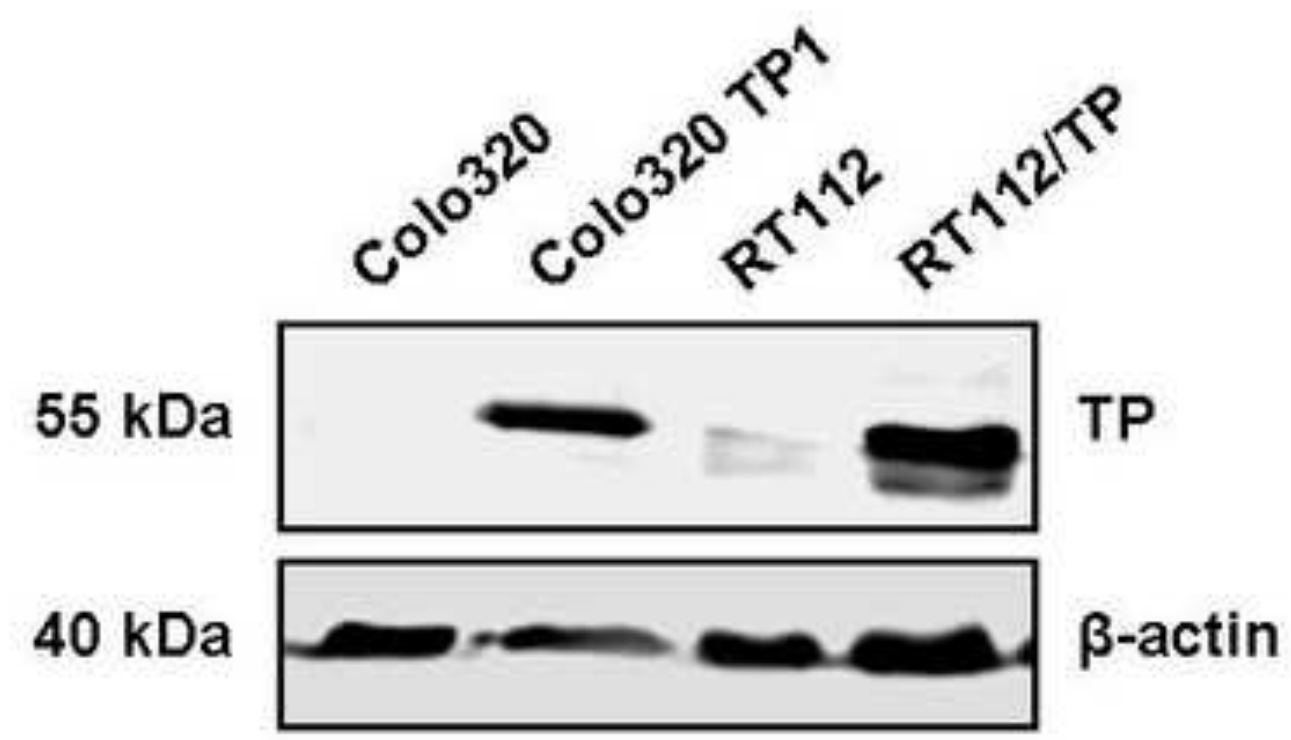




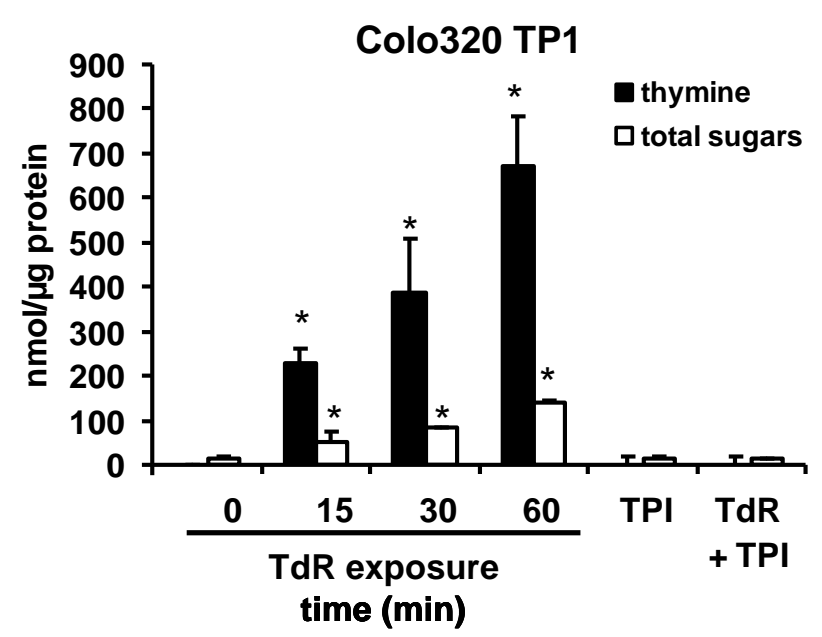

Colo320 TP1
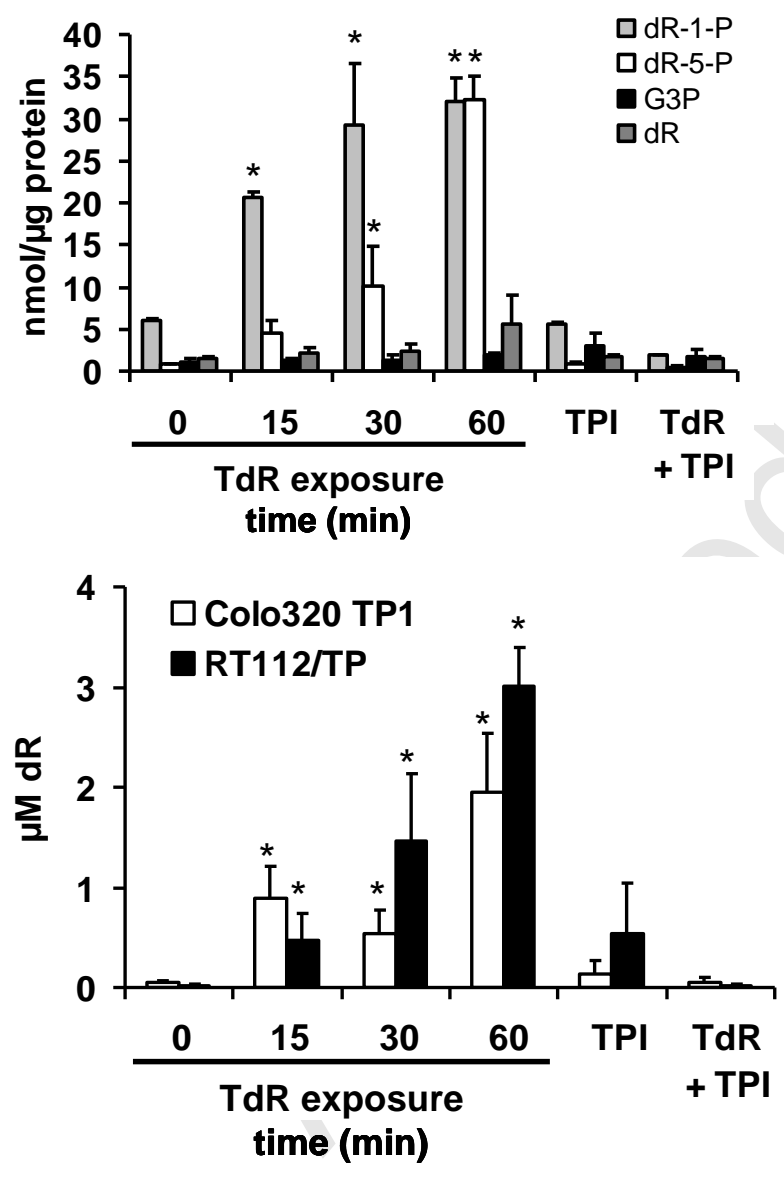

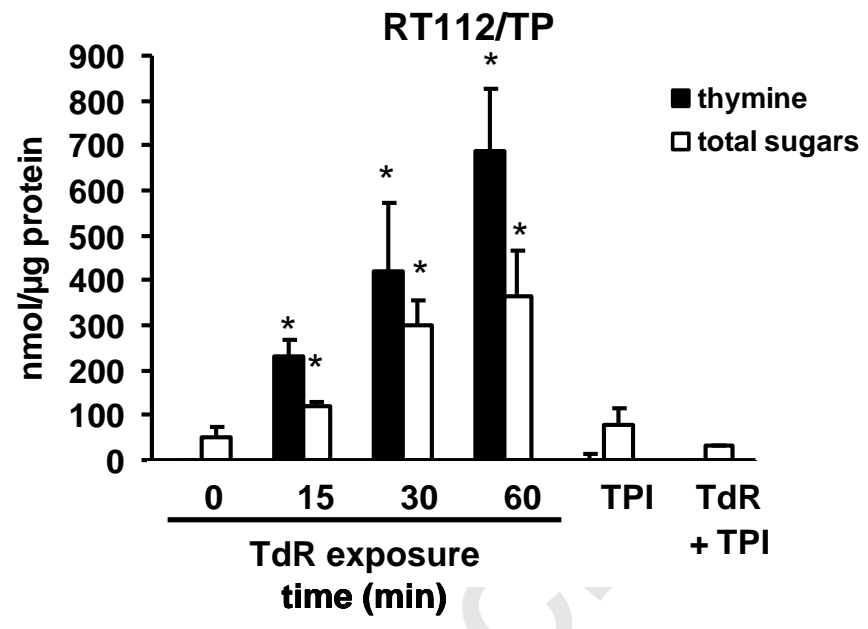

RT112/TP

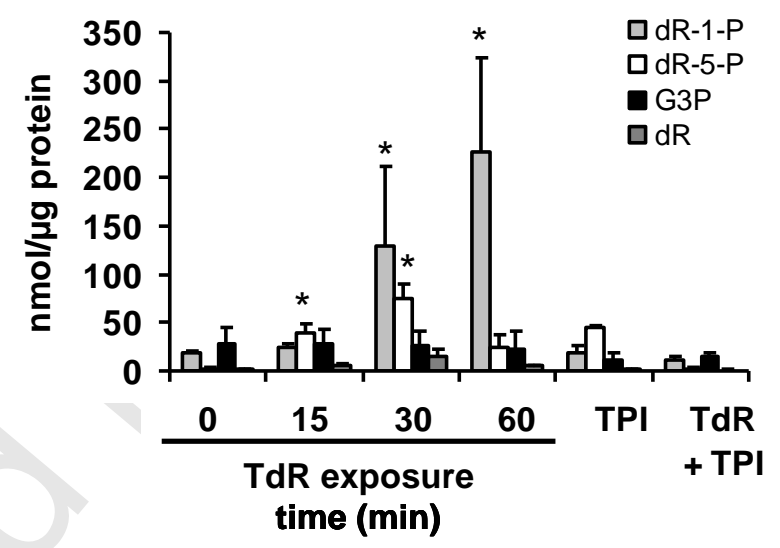


A
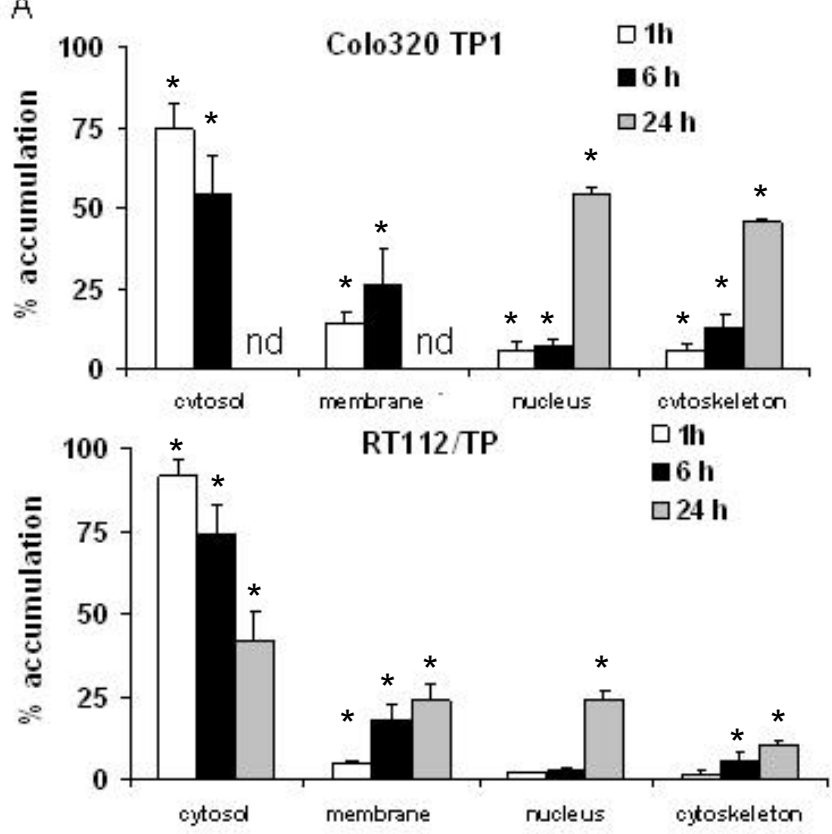

B

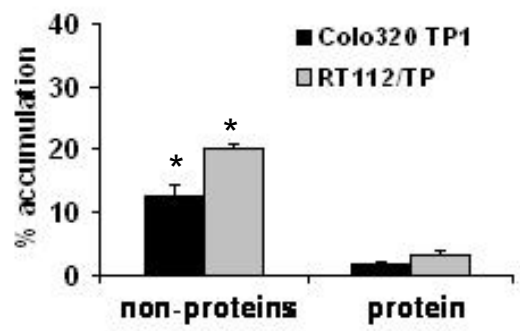


$\mathrm{TdR} \longrightarrow \mathrm{DNA}$

$\mid T P$

dR-1-P

+ thymine

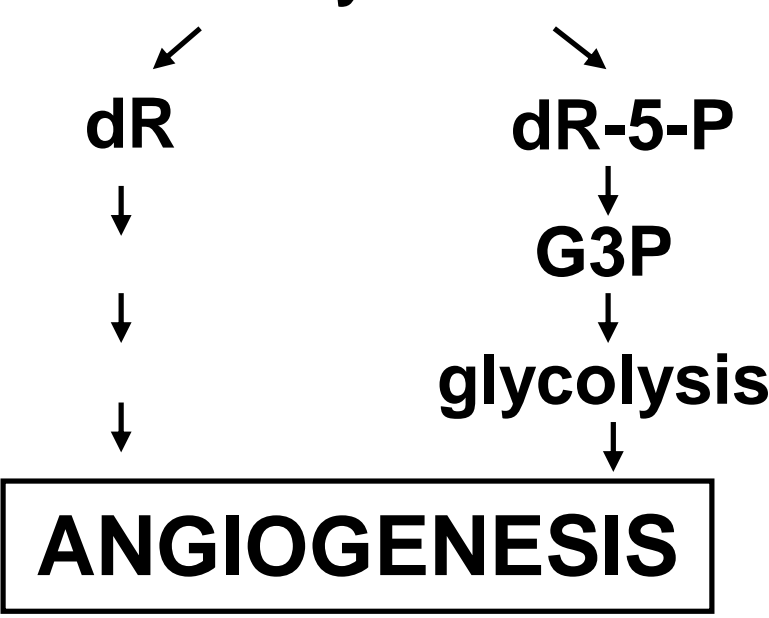

Thymidine $(\mathrm{TdR})$ is converted by thymidine phosphorylase (TP) to deoxyribose-1phosphate (dR-1-P), which can enter various metabolic pathways, which potentially contribute to TP mediated angiogenesis. $\mathrm{dR}=$ deoxyribose, $\mathrm{dR}-1-\mathrm{P}=$ deoxyribose -1 phosphate, $\mathrm{dR}-5-\mathrm{P}=$ deoxyribose-5phosphate, G3P=glyceraldehyde-3phosphate 
overexpressing cells

\author{
I.V. Bijnsdorp ${ }^{1}$, K. Azijli ${ }^{1}$, E.E. Jansen ${ }^{2}$, M.M. Wamelink ${ }^{2}$, C. Jakobs ${ }^{2}$, E.A. Struys ${ }^{2}$, M. \\ Fukushima $^{3 i}$, F.A.E. Kruyt ${ }^{4}$, G.J. Peters ${ }^{1 * i i}$
}

1. VU University Medical Center, Department Medical Oncology, Amsterdam, The

Netherlands

2. VU University Medical Center, Department of Clinical Chemistry, Metabolic Unit,

Amsterdam, The Netherlands

3. Tokushima research center, Taiho pharmaceuticals Co., ltd., Tokushima, Japan

4. University Medical Center Groningen, Department of Medical Oncology, Groningen, the

Netherlands

* Corresponding author

Prof. Dr. G.J. Peters

De Boelelaan 1117 CCA 1.42

1081 HV Amsterdam

The Netherlands

gj.peters@ @umc.nl

Tel: +31204442630

FAX: +31204443844

\title{
Category: Antibiotics and chemotherapeutics
}

\begin{abstract}
Abbreviations: TP: thymidine phosphorlylase; TdR: thymidine; G3P: glyceraldehyde-3phosphate; dR: deoxyribose; dR-1-P: deoxyribose-1-phosphate; dR-5-P: deoxyribose-5phosphate; TPI: thymidine phosphorylase inhibitor; AGE: advanced glycation endproducts; VEGF: vascular endothelial growth factor; IL-8: interleukin-8
\end{abstract}

\footnotetext{
${ }^{\mathrm{i}}$ Employee of Taiho pharmaceuticals Co., ltd.

ii Received financial support from Taiho pharmaceuticals Co., ltd.
} 


\section{ABSTRACT}

Thymidine phosphorylase (TP) is often overexpressed in cancer and potentially plays a role in the stimulation of angiogenesis. The exact mechanism of angiogenesis induction is unclear, but is postulated to be related to thymidine-derived sugars. TP catalyzes the conversion of thymidine (TdR) to thymine and deoxyribose-1-phosphate (dR-1-P), which can be converted to dR-5-P, glyceraldehyde-3-phosphate (G3P) or deoxyribose (dR). However, it is unclear which sugar accumulates in this reaction. Therefore, in the TP overexpressing Colo320 TP1 and RT112/TP cells we determined by LC-MS/MS which sugars accumulated, their subcellular localization (using ${ }^{3} \mathrm{H}-\mathrm{TdR}$ ) and whether $\mathrm{dR}$ was secreted from the cells. In both TP-overexpressing cell lines, dR-1-P and dR-5-P accumulated intracellularly at high levels and $\mathrm{dR}$ was secreted extensively by the cells. A specific inhibitor of TP completely blocked TdR conversion, and thus no sugars were formed. To examine whether these sugars may be used for the production of angiogenic factors or other products, we determined with ${ }^{3} \mathrm{H}-\mathrm{TdR}$ in which subcellular location these sugars accumulated. TdR-derived sugars accumulated in the cytoskeleton and to some extent in the cell membrane, while incorporation into the DNA was responsible for trapping in the nucleus. In conclusion, various metabolic routes were entered, of which the TdR-derived sugars accumulated in the cytoskeleton and membrane. Future studies should focus on which exact metabolic pathway is involved in the induction of angiogenesis. 


\section{Introduction}

The platelet derived endothelial cell growth factor (PD-ECGF) or thymidine phosphorylase (TP) is often overexpressed in human cancers, which has been related to a higher microvessel density, a higher tumor stage and the induction of metastasis [1,2,3,4]. In various in vitro studies, TP had a chemotactic effect on endothelial cells $[5,6,7,8]$. In vivo, TP induced angiogenesis using various cancer cell lines that were transfected with TP $[9,10]$. The role of $\mathrm{TP}$ in angiogenesis seems evident, but its exact mechanism is still unknown and it is postulated to be related to the sugars that are formed from thymidine (TdR) degradation by TP.

Deoxy- $\alpha$-D-ribose-1-phosphate (dR-1-P) and thymine are the first products that are formed by the phosphorylysis of TdR by TP (Fig. 1) [11]. After its formation, dR-1-P rapidly disappears, possibly by conversion to 2-deoxy-D-ribose (dR) or 2-deoxyribose-5-phosphate (dR-5-P) [12]. dR-5-P can be converted to glyceraldehyde-3-phosphate (G3P), which can enter the glycolytic or pentose phosphate pathway. dR can form advanced glycation end products (AGE) or reactive oxygen species (ROS) by Schiff base reactions [13]. The Schiff base is formed from either $\mathrm{dR}$ or $\mathrm{dR}-5-\mathrm{P}$, which can be coupled to an intracellular protein by nonenzymatic condensation between the sugar's aldehyde group and a lysine residue. This Schiff base can subsequently rearrange to an Amadori product, such as an $\alpha$-hydroxyketone, which may also form an enediol intermediate [14].These unstable intermediates react via nonenzymatic reactions to form AGEs. During these reactions, specifically in the transition metal-catalyzed auto-oxidation, free radicals are produced $[15,16,17]$. The formation of AGE from these reactions could be responsible for the angiogenic activity of TP [13].

The enzymatic activity of TP is indispensable for the angiogenic effect, since a competitive inhibitor of TP could block the angiogenic effect [18]. Therefore, substrate and metabolites from the reaction are often used for studying the angiogenic effect of TP [19]. 
The metabolite $\mathrm{dR}$ has previously shown angiogenic activity $[6,10]$ and could elongate the sprouting in the aortic ring assay [19]. In addition, $\mathrm{dR}$ induced endothelial cell migration in various studies $[5,8]$. The association between TP activity and angiogenesis is based on the potential accumulation of TdR-derived sugars. However, little is known about the cellular metabolism of dR-1-P. Although $\mathrm{dR}$ is considered the main factor causing the angiogenic switch, the real identity and extent of formation of TdR-derived sugars remains unclear. dR-1$\mathrm{P}$ rapidly disappears after its formation and its conversion could be reduced by addition of dR5-P [11]. The aim of the present study was to characterize the specific sugars that can be formed by the TP reaction, their subcellular localization and whether they are secreted by the cancer cells, enabling endothelial cells to migrate and invade towards tumor sites.

\section{Materials and Methods}

\subsection{Cell culture and chemicals}

The human colon carcinoma cell line Colo320 TP1 was a variant of Colo320 (obtained from the ATCC), transfected with TP, as described previously [20]. RT112/TP was a kind gift of Dr. Bicknell (Oxford, UK). Cells were cultured as monolayers in DMEM, supplemented with $10 \%$ heat inactivated FCS and $20 \mathrm{mM}$ Hepes in $25 \mathrm{~cm}^{2}$ culture flasks (Greiner Bio-One, Frickenhausen, Germany). Cells were maintained in a humidified $5 \% \mathrm{CO}_{2}$ atmosphere at $37^{\circ} \mathrm{C}$. TPI was provided by Taiho Pharmaceutical, Co., Ltd. (Tokushima, Japan). TdR, thymine, dR, dR-1-P, dR, dR-5-P and G3P were obtained from Sigma Aldrich Chemicals (Zwijndrecht, the Netherlands). These chemicals were dissolved in PBS in stock solutions of 1-20 $\mathrm{mM}$ and stored at $-20{ }^{\circ} \mathrm{C} .{ }^{13} \mathrm{C}_{6}$-glucose-6-phosphate (prepared as previously described [21]) and ${ }^{13} \mathrm{C}_{2}$-xylulose were obtained from Omicron biochemicals (South Bend, IN, USA). Ethoxyamine was obtained from Acros (Geel, Belgium) and pyridine from Merck (Darmstadt,

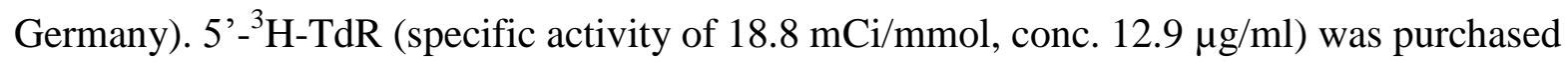


from Moravek Biochemicals Inc. (Brea, CA, USA). The exact moiety where the sugar of the TdR is labelled is indicated in Fig. 1. The thymidine phosphorylase antibody was purchased from R\&D systems Inc. (Minneapolis, MN USA) and the thymidine kinase antibody was purchased from QED Bioscience (San Diego, CA, USA). The secondary antibody, goat- $\alpha$ mouse-IRDye (800CW;\#926-32210 and 680;\#926-32220) was obtained from Westburg (Leusden, the Netherlands).

\subsection{Treatment of the cells}

For measurement of TdR and its sugars, Colo320TP1 and RT112/TP cells were seeded at $2 \times 10^{6}$ cells/flask. After $48 \mathrm{~h}$, cells were exposed to $100 \mu \mathrm{M}$ TdR for $0 \mathrm{~min}, 15 \mathrm{~min}, 30 \mathrm{~min}$ and $60 \mathrm{~min}$. TPI $(10 \mu \mathrm{M})$ was added $24 \mathrm{~h}$ prior to TdR exposure, after which samples were incubated for 60 min. After treatment, cells were trypsinized, washed in PBS and centrifuged for $5 \mathrm{~min}$ at $323 \mathrm{~g}$ at room temperature (RT). The medium and the cell pellets were stored separately at $-80^{\circ} \mathrm{C}$ until sample preparation.

\subsection{Measurement of TP enzymatic activity and of TdR and thymine}

HPLC measurement of TP enzymatic activity was performed as described previously [22] and is based on the detection of both TdR and thymine [23]. After incubation with thymidine, 25 $\mu 180 \%$ trichloroacetic acid (TCA) was added to the samples, which were left on ice for 20 min. Subsequently, samples were centrifuged at $14000 \mathrm{~g}$ at $4^{\circ} \mathrm{C}$ for $10 \mathrm{~min}$. The supernatant was transferred to a new vial, and the $\mathrm{pH}$ was neutralized. Samples were mixed and centrifuged for $1 \mathrm{~min}$ at $14000 \mathrm{~g}$. The upper aqueous layer was used for analysis of TdR and thymine by HPLC analysis for nucleosides with UV detection as described previously [23]. 


\subsection{Measurement of sugar-phosphates}

For sample preparation, the cell pellet was dissolved in $500 \mu \mathrm{l} \mathrm{MQ}$ and subsequently samples were sonificated $3 \mathrm{x}$ for 3 seconds on ice. $5 \mu \mathrm{M}{ }^{13} \mathrm{C}_{6}$-glucose-6-phosphate was used as an internal standard. The samples were centrifuged through a filter with $10 \mathrm{kDa}$ cut off (Ultracel YM-10; \#42407; Amicon Micron, Millipore, Billerica, MA, USA). Subsequently, the samples were injected into the LC-MS/MS as described previously [24]. The amount of sugars was expressed based on the total protein content of each sample that was measured before centrifugation through the $10 \mathrm{kDa}$ cut off filter. Protein concentration was determined using the BioRad Protein assay (\#500-0006; Bio-Rad Laboratories, Veenendaal, The Netherlands) according to manufacture's instruction.

\subsection{Measurement of $d R$}

For preparation of the samples for the $\mathrm{dR}$ measurement, the cell pellet was dissolved in 150 $\mu \mathrm{L}$ distilled water. ${ }^{13} \mathrm{C}_{2}$-xylulose was used as internal standard. $17 \mu \mathrm{l}$ of $20 \mu \mathrm{M}{ }^{13} \mathrm{C}_{2}$-xylulose was added to $50 \mu 1$ of the sample. To deproteinize the sample, $200 \mu 1$ methanol was added. After $15 \mathrm{~min}$, the sample was centrifuged for $10 \mathrm{~min}$ at $10000 \mathrm{~g}$ at $4^{\circ} \mathrm{C}$. Following this, the supernatant was transferred to a new vial and evaporated to dryness under a slight stream of nitrogen. Ethoxime derivatives of $\mathrm{dR}$ were formed by treating the residue with $2 \mathrm{mg}$ ethoxyamine in $100 \mu \mathrm{l}$ pyridine at $60^{\circ} \mathrm{C}$ for $30 \mathrm{~min}$. After cooling down to RT, the hydroxygroups were acetylated by adding $100 \mu \mathrm{l}$ acetic anhydride at $80^{\circ} \mathrm{C}$ for $60 \mathrm{~min}$. This solution was evaporated to dryness and the residue was redissolved in ethylacetate. 1-2 $\mu$ l was injected into the GC-MS operating under positive chemical ionization in the single ion monitoring mode. 


\subsection{Separation of cell compartments}

Colo320 TP1 and RT112/TP cells $\left(1.5 \times 10^{6}\right.$ cells) were exposed to $200 \mu \mathrm{M}$ TdR (hot:cold $(1: 21)$ of which the batch of $\left[5^{,}-{ }^{3} \mathrm{H}\right]-\mathrm{TdR}$ was mixed with $1 \mathrm{mM}$ unlabeled TdR). After incubation for 1,6 or $24 \mathrm{~h}$ or $1 \mathrm{~h}$ plus $24 \mathrm{~h}\left[5^{,}-{ }^{3} \mathrm{H}\right]-\mathrm{TdR}$-free medium at $37^{\circ} \mathrm{C}$, cell fractions were separated using a ProteoExtract ${ }^{\circledR}$ Subcellular Proteome Extraction Kit according to manufacture's instructions (Calbiochem, San Diego, CA). Of every cell fraction, including from the medium above the cells after the designated incubation times, $5 \mu l$ was counted. To determine to which fraction (protein or non-protein fraction) secreted $\left[5^{,}-{ }^{3} \mathrm{H}\right]-\mathrm{TdR}$-derived metabolites accumulated, $100 \mu \mathrm{l}$ of the medium above the cells after the retention was precipitated with $60 \mu 135 \%$ TCA for 20 min on ice. Subsequently, samples were centrifuged for $5 \mathrm{~min}$ at $300 \mathrm{~g}$ at $4^{\circ} \mathrm{C}$ and $5 \mu \mathrm{l}$ of the supernatant (non-protein fraction) was counted. In addition, the pellet (protein fraction) was recovered in $200 \mu 1 \mathrm{MQ}$, of which $5 \mu 1$ was counted.

\subsection{Western blotting}

Colo320, Colo320 TP1, RT112 and RT112/TP cells were washed twice with ice-cold PBS and lysed in lysis buffer (Cell Signalling Technology Inc., Denver, USA). Cell lysates were scraped, transferred into a vial and centrifuged at $11000 \mathrm{~g}$ at $4^{\circ} \mathrm{C}$ for $10 \mathrm{~min}$. Supernatants were transferred to a new vial and protein amounts were determined by the Bio-Rad assay, according to the manufacturer's instruction (Bio-Rad Laboratories, Veenendaal, the Netherlands). From each condition $30 \mu \mathrm{g}$ of protein was separated on a $10 \%$ SDS-PAGE and electroblotted onto polyvinylidenedifluoride (PVDF) membranes (Millipore Immobilon ${ }^{\mathrm{TM}}$ FL PVDF, $0.45 \mu \mathrm{m})$. Subsequently, the membranes were blocked for $1 \mathrm{~h}$ at room temperature (RT) in Odyssey blocking buffer (Odyssey blocking buffer \#927-40003, Westburg, Leusden, The Netherlands) and incubated overnight at $4{ }^{\circ} \mathrm{C}$ with the primary antibodies (dilution 1:1000-10000 in Odyssey blocking buffer 1:1 diluted with PBS-T (PBS with 0.05\% Tween- 
20). The membrane was washed 5 times in PBS-T and incubated with the secondary antibodies (1:10000) for $1 \mathrm{~h}$ at RT in the dark. After incubation, the membrane was washed in PBS-T and followed by 5 min washing in PBS without Tween-20 to decrease the background signal. Subsequently, the bands were scanned using an Odyssey Infrared Imager (LI-COR Biosciences, Lincoln, Nebraska USA), $0 \mathrm{~mm}$ offset, $84 \mu \mathrm{m}$ resolution and with high quality $[25]$.

\subsection{Statistical analysis}

Potential differences between controls and TdR exposed cells were evaluated using the twotailed Student's $t$-test for paired data. Changes were considered significantly different when $\mathrm{p}<0.05$.

\section{Results}

\subsection{TdR conversion to thymine}

In order to determine the extent of TdR conversion, TdR and thymine levels were measured, after incubation with $100 \mu \mathrm{M}$ TdR for 15,30 and $60 \mathrm{~min}$. As expected, the parental Colo320 and RT112 cells did not or hardly convert TdR to thymine, since these cells do not or hardly express TP (Fig 2) [20] TP was highly expressed in both Colo320 TP1 and RT112/TP cells (Fig 2), while no band could be detected in Colo320 parental cells and a very faint band was found in RT112 cells. Colo320 and RT112 cells converted thymidine at a rate of $0 \pm 0$ and $3 \pm$ $0.04 \mathrm{nmol} /$ million cells / $\mathrm{h}$, respectively. Colo320 TP1 and RT112/TP converted thymidine at a rate of $518 \pm 40 \mathrm{nmol} / \mathrm{million}$ cells $/ \mathrm{h}$ and $418 \pm 34 \mathrm{nmol} / \mathrm{million}$ cells $/ \mathrm{h}$ (Fig. 3A). After 1 $\mathrm{h}$ incubation of intact cells with $\mathrm{TdR}$, the extracellular thymine concentrations were 24 and 30 $\mu \mathrm{M}$, respectively. The TK protein, which activates TdR for DNA synthesis, was similarly expressed in the TP-transfected cells (data not shown). 


\subsection{Intracellular accumulation of $d R-5-P$ and $d R$ -}

TP degrades TdR into one molecule of thymine and one dR-1-P, which can be metabolized to other sugars (Fig. 1). We measured the intracellular levels of the potential metabolites dR-1-P, dR-5-P, dR and G3P in Colo320, RT112 and the transfected variants, Colo320 TP1 and RT112/TP. In the cells that did not express TP, no sugars accumulated at all (data not shown), which is in agreement with the absence of thymine formation. In general, the sugars accumulated to a much higher extent in RT112/TP cells, compared to Colo320 TP1 cells (Fig. 3A and 3B). dR-1-P increased rapidly, and was about 10 fold higher in RT112/TP cells compared to Colo320 TP1 cells. dR-1-P was rapidly metabolized to dR-5-P and dR. In both Colo320TP1 and RT112/TP cells, dR-1-P was the major intracellular metabolite (Fig. 3B). In RT112/TP cells, the accumulation of dR-5-P was lower than the level of dR-1-P. dR accumulated intracellularly to a low extent in Colo320TP1 cells and was only 4 fold increased compared to the control dR level. In RT112/TP cells, dR hardly accumulated. In Colo320 TP1 cells, G3P increased only at very low levels, with a 2 fold increase compared to the control. G3P did not accumulate in RT112/TP cells.

Addition of TPI alone to the cultures did not alter the production of the tested sugars. TPI completely blocked the conversion of TdR in Colo320 TP1 and RT112/TP cells (Fig. $3 \mathrm{~A})$, which is in agreement with the formation of the sugars, which were not formed at all (Fig. 3A and 3B).

\section{$3.3 d R$ is secreted from the cells}

$\mathrm{dR}$ is an important angiogenic sugar that can be secreted by the cells [7,13]. Therefore, we determined the level of $\mathrm{dR}$ in the medium. $\mathrm{dR}-1-\mathrm{P}$ and $\mathrm{dR}-5-\mathrm{P}$ can not cross the membrane, because of the negative charge of the phosphate group on these sugars. In the medium above 
Colo320 TP1 and RT112/TP cells, dR increased in time (Fig. 3C) and was found at higher levels than the other sugars intracellularly (Table 1). Of the total thymine detected, 10 and 13 $\%$ was measured as extracellular dR after 1 h by Colo320 TP1 and RT112/TP cells, respectively (Table 1). TPI alone did not have any effect on the intracellular levels of $\mathrm{dR}$, while TPI prevented dR from being formed (Fig. 3C).

\subsection{Thymidine-derived sugars and accumulation levels}

Since the thymine levels are representative for the total amount of sugars that are formed, we compared each value with the amount of thymine (in which thymine was set at $100 \%$ for each time point) (Table 1). In Colo320 TP1 cells, the total amount of measured sugars was much lower than that of RT112/TP cells (Fig. 3A). In Colo320 TP1 cells, about 20\% of the total TdR-derived sugars presented intracellularly as dR-1-P, dR-5-P, $\mathrm{dR}$ and G3P and extracellular $\mathrm{dR}$. This did not increase after a longer exposure time to TdR, indicating that the sugars are rapidly metabolized to other products. In RT112/TP cells, about $50 \%$ of the TdRderived sugars were measured (Table 1), indicating a slower metabolism of these sugars into other products compared to that in Colo320 TP1 cells.

\subsection{Accumulation in the cytoskeleton and nucleus}

In order to determine in which cellular compartment the converted products of $\mathrm{TdR}$ accumulated, Colo320 TP1 and RT112/TP cells were exposed to $\left[5^{\prime}-{ }^{3} \mathrm{H}\right]-\mathrm{TdR}$ for different time periods. Subsequently, subcellular cell fractions were separated and the amount of radioactivity was determined in each compartment (Fig. 4).

In Colo320 TP1 cells, the level of $\left[5^{,}-{ }^{3} \mathrm{H}\right]$-products in the cytosolic compartment decreased in time, until it was hardly detectable after $24 \mathrm{~h}$. Products in the membrane fraction increased to some extent after $6 \mathrm{~h}$, while after $24 \mathrm{~h}$ hardly any radioactivity was detectable in 
this fraction. In the nuclear fraction, the radioactivity was increased after $24 \mathrm{~h}$, which was about $55 \%$ of the total intracellular radioactivity. This is possibly in part due to metabolic activation of TdR by thymidine kinase, resulting in incorporations into the DNA and nuclear trapping. Interestingly, TdR-derived radioactivity was present in the cytoskeletal protein fraction, which increased in time up to about $45 \%$ after $24 \mathrm{~h}$.

In RT112/TP cells, the radioactivity in the cytosolic fraction decreased in time, with about $45 \%$ of $\left[5^{\prime}-{ }^{3} \mathrm{H}\right]$-products still detectable after $24 \mathrm{~h}$ (Fig. 4). This is in agreement with the lower metabolism of the sugars in these cells, as measured by LC-MS/MS (Table 1). Comparable to Colo320 TP1 cells, the radioactive products in the nuclear fraction increased in RT112/TP cells, although at lower levels; up to $25 \%$ after $24 \mathrm{~h}$. Both the membrane and cytoskeleton fraction increased in time, with a maximum of about $25 \%$ and $10 \%$ after $24 \mathrm{~h}$ incubation, respectively.

When the $\left[5{ }^{\prime}-{ }^{3} \mathrm{H}\right]-\mathrm{TdR}$ was washed away following $1 \mathrm{~h}$ incubation, the radioactivity was found to a high extent in the membrane (9.6 and 13.6\%) and cytoskeletal (73.5 and 39.4 \%) compartments of both Colo320 TP1 and RT112/TP cells, respectively (data not shown). Hardly any of the radioactive label retained in the nuclear fraction, which may be related to a lack of activation of TdR by TK within $1 \mathrm{~h}$ exposure. In summary, the TdR-sugars are used in the cytoskeletal and membrane, which may possibly be related to protein-glycation.

\subsection{Secreted products are in the non-protein fraction}

To determine whether products were secreted after conversion of TdR, Colo320 TP1 and RT112/TP cells were exposed to $\left[5^{\prime}-{ }^{3} \mathrm{H}\right]-\mathrm{TdR}$ for $1 \mathrm{~h}$, after which the medium was refreshed and cells were washed to remove the excess of $\left[5^{3}-{ }^{3} \mathrm{H}\right]-\mathrm{TdR}$. The amounts of secreted products were determined by analyzing the amount of radioactivity in the medium fraction. 
Both Colo320 TP1 and RT112/TP cells secreted radioactive products, with higher levels for RT112/TP (24\%) than for Colo320 TP1(15\%) cells.

To analyze whether the secreted products were in the protein or in the non-protein fraction, proteins were precipitated by adding TCA (Fig. 4B). In both Colo320 TP1 and RT112/TP cells, the largest part of the secreted radioactive products was found in the nonprotein fraction. This indicates that the sugars may not be used to a high extent for proteinglycation of secreted proteins, but may be more important for processes intracellularly.

\section{Discussion}

In this study we describe TdR phosphorylysis to $\mathrm{dR}-1-\mathrm{P}$, which is rapidly followed by its isomerization to $\mathrm{dR}-5-\mathrm{P}$ or degradation to $\mathrm{dR}$ of which the latter was extensively secreted. To our knowledge, the formation of these sugars using human (eukaryotic) cells has not been described earlier. We observed different levels of accumulation of TdR-derived sugars in the two cell types. In addition, the converted TdR was found in the cytoskeleton and to some extent in the cell membrane.

Previously we demonstrated that dR-1-P formed from TdR rapidly disappeared from Colo320 TP1 cells [11]. dR-1-P can be isomerized to dR-5-P mediated by phosphopentomutase (E.C. 5.4.2.7) and is degraded to dR by a phosphatase [10]. dR-5-P can be split into G3P plus acetaldehyde by deoxyriboaldolase (E.C. 4.1.2.4) [12,27]. The formed acetaldehyde may be converted into acetyl-CoA by aldehyde oxidase and acetyl-CoA synthetase [27]. G3P can enter several metabolic pathways, including the glycolytic and the pentose phosphate pathway, and possibly therefore did not accumulate in the cells in our study. Initially, these steps were only described in e.g. Bacillus ceresus [28]. Enzymatic activity needed for this pathway was also identified in epithelial anmoitic WISH cells [12]. The sugars may also be substrate in the formation of AGE (unpublished data), which may be 
used for protein glycation, e.g. adding sugar moieties to proteins by non-enzymatic reactions $[29,30]$. However, whether protein glycation of AGEs are formed in the cells used in our study, remains to be identified. Brown et al. previously reported a possible Schiff base reaction in RT112 cells, and demonstrated the presence of reactive oxygen species by expression levels of the oxidative stress marker heme oxygenase-1 (HO-1) [31].

$\mathrm{dR}-1-\mathrm{P}$ can also be formed by conversion of purine deoxynucleosides by purine nucleoside phosphorylase (PNP) [32]. Therefore theoretically, PNP may also be an angiogenic enzyme. However, to the best of our knowledge, a role for PNP in angiogenesis has never been described before. Important differences between TP and PNP involve their function: TP overexpression in tumor sites has clearly been related with angiogenesis [2], while PNP is involved in immune function [33,34]. In addition, PNP is hardly overexpressed in cancer $[33,34,35]$, making it less likely to be an angiogenic enzyme. It might be possible that other products than the sugars are involved in angiogenesis as well, such as $\beta$-Aminoiso-butyric acid, which is another downstream metabolite of thymine [19]. However, several enzymes involved in thymine catabolism (e.g. DPD and $\beta$-ureidopropionase) are usually low or not detectable in many tumors $[36,37,38]$. In our and other panels of colon cancer cell lines, DPD activity was low to not detectable [39, 40], in contrast to pancreatic and breast cancer $[40,41,42]$. Therefore, it is unlikely that $\beta$-Amino-iso-butyric acid is involved in the angiogenic activity of TP.

In the present study, we used cancer cells to determine the sugar metabolism in order to stimulate angiogenesis. TP expression in endothelial cells may also be important for their angiogenic properties. However, TP expression is very low in endothelial cells $[43,44]$. In addition, TP expression is often reported to be in either cancer cells or other tumor stromal cells such as fibroblasts. The angiogenic role of TP is possibly more related to the secretion of angiogenic factors (i.e. dR or chemoattractants such as IL-8) by cancer cells, rather than an 
autocrine stimulation by endothelial cells themselves. Therefore, the model that we used in the present study was intended to reflect the stimulation of angiogenesis by cancer cells.

Although TP is clearly associated with angiogenesis, the exact link between TdRrelated sugars and angiogenesis is still missing. Cells with a high TP can secrete angiogenic factors at high levels, including the vascular endothelial growth factor (VEGF) and interleukin-8 (IL-8), but the role of sugars in the activation of these factors remains unclear $[6,13]$. TdR-derived sugars accumulated in the cell fractions of the membrane and cytoskeleton, which may be related to glycation of proteins by the formation of AGE. This may lead to the hypothesis that protein glycation plays a role in the activation of the transcription of angiogenic factors, such as IL-8 and VEGF [13] which can subsequently be secreted. The secreted fraction consisted of non-proteins. This indicates that $\mathrm{dR}$ may be the main TdR-sugar-product that is secreted by TP-expressing cells. Possibly, protein-glycation of secreted proteins is not the main regulator of angiogenesis. Thus, glycation of proteins that remain intracellularly are possibly important for angiogenesis, by activating transcription of angiogenic enzymes. Since $\mathrm{dR}$ can be secreted by the cancer cells, it can be taken up by the endothelial cells, in which it can also undergo Schiff base reactions, forming AGE inside the endothelial cells, stimulating their angiogenic properties (Fig. 1).

A possible role of sugars in the angiogenic potential of TP was studied through its metabolite $\mathrm{dR}$, which can stimulate endothelial cell migration and angiogenesis. $\mathrm{dR}$ is a strongly reducing sugar that can generate oxygen radical species during the early stages of protein glycation [13]. dR can bind to an amino group of proteins by a non-enzymatic reaction. This leads to the formation of a Schiff base, which can subsequently rearrange to an $\alpha$-hydroxyketone. During this reaction, free oxygen radicals are produced. Thus, through the formation of $\mathrm{dR}$, TP induces oxidative stress in TP-overexpressing tumor cells. This may result in the secretion of angiogenic factors, such as VEGF or IL-8 [13]. dR secreted by the 
cancer cells may in this way directly or indirectly (by its conversion to other sugars) stimulate angiogenesis. $\mathrm{dR}$ was secreted by the cancer cells in our study, indicating that $\mathrm{dR}$ can directly play a role in the angiogenic potential of TP.

In conclusion, $\mathrm{dR}-1-\mathrm{P}$ and subsequently $\mathrm{dR}-5-\mathrm{P}$ and $\mathrm{dR}$ are formed from $\mathrm{TdR}$ conversion by TP. Both metabolites may stimulate angiogenesis, e.g. by the stimulation of angiogenic factors, while secreted dR may attract endothelial cells to form new blood vessels in the tumor tissue. The sugars formed from TdR will accumulate in the membrane and cytoskeleton of the cells, indicating that the sugars are used for further cellular metabolism, possibly mediating angiogenesis in a more indirect manner. 


\section{References}

[1] de Bruin M, Temmink OH, Hoekman K, Pinedo HM, Peters GJ. Role of platelet derived endothelial cell growth factor/ thymidine phosphorylase in health and disease. Cancer therapy 2006;4:99-124.

[2] Bronckaers A, Gago F, Balzarini J, Liekens S. The dual role of thymidine phosphorylase in cancer development and chemotherapy. Med Res Rev. 2009;29:903-53.

[3] Liekens S, Bronckaers A, Pérez-Pérez MJ, Balzarini J. Targeting platelet-derived endothelial cell growth factor/thymidine phosphorylase for cancer therapy. Biochem Pharmacol 2007;74:1555-67.

[4] Koukourakis MI, Giatromanolaki A, Kakolyris S, O'Byrne KJ, Apostolikas N, Skarlatos J, et al. Different patterns of stromal and cancer cell thymidine phosphorylase reactivity in non-small-cell lung cancer: impact on tumour neoangiogenesis and survival. Br J Cancer 1998;77:1696-1703.

[5] Ishikawa F, Miyazono K, Hellman U, Drexler H, Wernstedt C, Hagiwara K, et al. Identification of angiogenic activity and the cloning and expression of platelet-derived endothelial cell growth factor. Nature 1989;338:557-62.

[6] Hotchkiss KA, Ashton AW, Schwartz EL. Thymidine phosphorylase and 2-deoxyribose stimulate human endothelial cell migration by specific activation of the integrins alpha 5 beta 1 and alpha V beta 3. J Biol Chem 2003;278:19272-9.

[7] Hotchkiss KA, Ashton AW, Klein RS, Lenzi ML, Zhu GH, Schwartz EL. Mechanisms by which tumor cells and monocytes expressing the angiogenic factor thymidine phosphorylase mediate human endothelial cell migration. Cancer Res 2003;63:527-533.

[8] Seeliger H, Guba M, Koehl GE, Doenecke A, Steinbauer M, Bruns CJ, et al. Blockage of 2-deoxy-D-ribose-induced angiogenesis with rapamycin counteracts a thymidine 
phosphorylase-based escape mechanism available for colon cancer under 5-fluorouracil therapy. Clin Cancer Res 2004;10:1843-52.

[9] Moghaddam A, Zhang HT, Fan TP, Hu DE, Lees VC, Turley H, et al. Thymidine phosphorylase is angiogenic and promotes tumor growth. Proc Natl Acad Sci U S A 1995;92:998-1002.

[10] Sengupta S, Sellers LA, Matheson HB, Fan TP. Thymidine phosphorylase induces angiogenesis in vivo and in vitro: an evaluation of possible mechanisms. Br J Pharmacol 2003;139:219-31.

[11] de Bruin M, Smid K, Laan AC, Noordhuis P, Fukushima M, Hoekman K, et al. Rapid disappearance of deoxyribose-1-phosphate in platelet derived endothelial cell growth factor/thymidine phosphorylase overexpressing cells. Biochem Biophys Res Commun 2003;301:675-9.

[12] Carta MC, Mattana A, Camici M, Allegrini S, Tozzi MG, Sgarrella F. Catabolism of exogenous deoxyinosine in cultured epithelial amniotic cells. Biochim Biophys Acta 2001;1528:74-80.

[13] Brown NS, Jones A, Fujiyama C, Harris AL, Bicknell R. Thymidine phosphorylase induces carcinoma cell oxidative stress and promotes secretion of angiogenic factors. Cancer Res 2000;60:6298-6302.

[14] Wolff S. P., Crabbe M. J. C., Thornalley P. J. The autoxidation of glyceraldehyde and other simple monosaccharides. Experientia (Basel), 1984;40: 244-246.

[15] Wolff S. P., Dean R. T. Glucose autoxidation and protein modification. The potential role of "autoxidative glycosylation" in diabetes. Biochem. J. 1987;245: 243-250.

[16] Monnier VM (1990) Nonenzymatic glycosylation, the Maillard reaction and the aging process. J Gerontol 45: B105-B111 
[17] Bierhaus A, Hofmann MA, Ziegler R, Nawroth PP (1998) AGEs and their interaction with AGE-receptors in vascular disease and diabetes mellitus. I. The AGE concept. Cardiovasc Res 37: 586-600

[18] Haraguchi M, Miyadera K, Uemura K, Sumizawa T, Furukawa T, Yamada K, et al. Angiogenic activity of enzymes. Nature 1994;368:198.

[19] Stevenson DP, Milligan SR, Collins WP. Effects of platelet-derived endothelial cell growth factor/thymidine phosphorylase, substrate, and products in a three-dimensional model of angiogenesis. Am J Pathol 1998;152:1641-1646.

[20] de Bruin M, van Capel T, Van der Born K, Kruyt FA, Fukushima M, Hoekman K, et al. Role of platelet-derived endothelial cell growth factor/thymidine phosphorylase in fluoropyrimidine sensitivity. Br J Cancer 2003;88:957-64.

[21] Huck JH, Struys EA, Verhoeven NM, Jakobs C, van der Knaap MS. Profiling of pentose phosphate pathway intermediates in blood spots by tandem mass spectrometry: application to transaldolase deficiency. Clin Chem 2003;49:1375-80.

[22] de Bruin M, Peters GJ, Oerlemans R, Assaraf YG, Masterson AJ, Adema AD, et al. Sulfasalazine down-regulates the expression of the angiogenic factors platelet-derived endothelial cell growth factor/thymidine phosphorylase and interleukin-8 in human monocytic-macrophage THP1 and U937 cells. Mol Pharmacol 2004; 66:1054-60.

[23] Laurensse EJ, Pinedo HM, Peters GJ. A sensitive non-radioactive assay for pyrimidine nucleoside phosphorylase using reversed-phase high performance liquid chromatography. Clin Chim Acta 1988; 178:71-8.

[24] Wamelink MM, Struys EA, Huck JH, Roos B, van der Knaap MS, Jakobs C, et al. Quantification of sugar phosphate intermediates of the pentose phosphate pathway by LCMS/MS: application to two new inherited defects of metabolism. J Chromatogr B Analyt Technol Biomed Life Sci 2005;823:18-25. 
[25] Mathews ST, Plaisance EP, Kim T. Imaging systems for westerns: chemiluminescence vs. infrared detection. Methods Mol Biol. 2009;536:499-513.

[26] Sgarrella F, Poddie FP, Meloni MA, Sciola L, Pippia P, Tozzi MG. Channelling of deoxyribose moiety of exogenous DNA into carbohydrate metabolism: role of deoxyriboaldolase. Comp Biochem Physiol B Biochem Mol Biol 1997;117:253-7.

[27] Moriwaki Y, Yamamoto T, Yamakita J, Takahashi S, Higashino K. Comparative localization of aldehyde oxidase and xanthine oxidoreductase activity in rat tissues. Histochem J 1998;30:69-74.

[28] Sgarrella F, Del Corso A, Tozzi MG, Camici M. Deoxyribose 5-phosphate aldolase of Bacillus cereus: purification and properties. Biochim Biophys Acta 1992;1118:130-3.

[29] Cho SJ, Roman G, Yeboah F, Konishi Y. The road to advanced glycation end products: a mechanistic perspective. Curr Med Chem 2007;14:1653-71.

[30] Monnier VM (1990) Nonenzymatic glycosylation, the Maillard reaction and the aging process. J Gerontol 45:B105-11.

[31] Brown NS, Streeter EH, Jones A, Harris AL, Bicknell R. Cooperative stimulation of vascular endothelial growth factor expression by hypoxia and reactive oxygen species: the effect of targeting vascular endothelial growth factor and oxidative stress in an orthotopic xenograft model of bladder carcinoma. Br J Cancer 2005;92:1696-701.

[32] Tozzi MG, Camici M, Mascia L, Sgarrella F, Ipata PL. Pentose phosphates in nucleoside interconversion and catabolism. FEBS J. 2006;273:1089-101.

[33] Pieters R, Huismans DR, Loonen AH, Peters GJ, Hählen K, van der Does-van den Berg A, van Wering ER, Veerman AJ. Adenosine deaminase and purine nucleoside phosphorylase in childhood lymphoblastic leukemia: relation with differentiation stage, in vitro drug resistance and clinical prognosis. Leukemia. 1992 May;6(5):375-80. 
[34] van Laarhoven JP, de Bruyn CH. Purine metabolism in relation to leukemia and lymphoid cell differentiation. Leuk Res. 1983;7(4):451-80.

[35] Bardot V, Dutrillaux AM, Delattre JY, Vega F, Poisson M, Dutrillaux B, Luccioni C. Purine and pyrimidine metabolism in human gliomas: relation to chromosomal aberrations. Br J Cancer. 1994 Aug;70(2):212-8.

[36] Westra JL, Hollema H, Schaapveld M, Platteel I, Oien KA, Keith WN, Mauritz R, Peters GJ, Buys CH, Hofstra RM, Plukker JT. Predictive value of thymidylate synthase and dihydropyrimidine dehydrogenase protein expression on survival in adjuvantly treated stage III colon cancer patients. Ann Oncol. 2005 Oct;16(10):1646-53. Epub 2005 Jul 12.

[37] Johnson MR, Diasio RB. Importance of dihydropyrimidine dehydrogenase (DPD) deficiency in patients exhibiting toxicity following treatment with 5-fluorouracil. Adv Enzyme Regul 2001; 41:151-157.

[38] Thomas HR, Ezzeldin HH, Guarcello V, Mattison LK, Fridley BL, Diasio RB. Genetic regulation of dihydropyrimidinase and its possible implication in altered uracil catabolism. Pharmacogenet Genomics. 2007;17:973-87.

[39] Peters GJ, van Groeningen CJ, Pinedo HM. Dihydropyrimidine dehydrogenase in livers from mouse and rat, and in human colon tumors, and mucosa in relation to anabolism of 5-fluorouracil. Adv Exp Med Biol. 1998;431:633-6.

[40] Beck A, Etienne MC, Chéradame S, Fischel JL, Formento P, Renée N, Milano G. A role for dihydropyrimidine dehydrogenase and thymidylate synthase in tumour sensitivity to fluorouracil. Eur J Cancer. 1994;30A:1517-22.

[41] Shimoda M, Sawada T, Kubota K. Thymidylate synthase and dihydropyrimidine dehydrogenase are upregulated in pancreatic and biliary tract cancers. Pathobiology. 2009;76:193-8. 
[42] Anan K, Mitsuyama S, Tamae K, Suehara N, Nishihara K, Ogawa Y, Abe Y, Iwashita T, Toyoshima S. Increased dihydropyrimidine dehydrogenase activity in breast cancer. J Surg Oncol. 2003;82:174-9.

[43] Bijnsdorp IV, Vrijland K, Vroling L, Peters GJ. Increased migration by stimulation of thymidine phosphorylase in endothelial cells of different origin. Nucleosides Nucleotides and Nucleic Acid, in press

[44] Pula G, Mayr U, Evans C, Prokopi M, Vara DS, Yin X, Astroulakis Z, Xiao Q, Hill J, Xu Q, Mayr M. Proteomics identifies thymidine phosphorylase as a key regulator of the angiogenic potential of colony-forming units and endothelial progenitor cell cultures. Circ Res. 2009;104:32-40. 